\title{
Suorakylvö muuttaa rikkakasvien tarkkailu- ja torjuntatarvetta
}

\author{
Heikki Jalli \\ MTT Kasvinsuojelu, 31600 Jokioinen, heikki.jalli@mtt.fi
}

\section{Johdanto}

Pellon muokkaus vaikuttaa kasvien elinmahdollisuuksiin monin tavoin. Kyntö ja kevyemmät muokkaukset pilkkovat, multaavat ja hautaavat kasvijätteitä ja rikkakasveja. Lopetettaessa muokkaukset peltojen rikkakasvillisuus alkaa muuttua lähemmäs muokkaamattomien alueiden ja pientareiden kasvillisuutta. Juurien ja juurakkojensa avulla leviäviä kestorikkakasveja ei häiritä, eikä mätästävien siemenlevintäisten heinäkasvien kasvua häiritä.

\section{Aineisto ja menetelmät}

MTT:ssä aloitettiin keväällä 2001 Mietoisissa ja Jokioisilla koesarja, jossa tutkitaan eri viljalajien soveltuvuutta suorakylvöön. Kummankin koepaikan maalaji on jäykkä savi. Kokeiden pääruutuina on muokkaus: kyntö tai sänki ja osaruutuina viljalaji: monitahoinen Rolfi-ohra ja kaksitahoinen Saanaohra, Roope-kaura ja Kruunu-kevätvehnä. Tässä käsitellään tilannetta Jokioisilla. Suorakylvöä edelsi viljely, jossa perusmuokkaus tehtiin kyntämällä ja rikkakasvit torjuttiin MCPA-valmisteella. Rikkasvihavainnot tehtiin kolme kertaa kasvukaudessa: ennen herdisidikäsittelyä, 5-6 viikkoa käsittelystä ja puinnin jälkeen.

\section{Tulokset ja tulosten tarkastelu}

Suorakylvettäessä talvehtivat monivuotiset ja syysyksivuotiset rikkakasvit, kuten saunakukka ja linnunkaali, eivät tuhoudu kun kylvömuokkaus jää pois. Talvehtineiden rikkakasvien lisäksi sängellä saavat mahdollisuuden kevätitoiset rikkakasvit, joiden siemenet ovat pellon pintakerroksessa. Peltomataraa taimettui runsaasti (yli 600 $\mathrm{kpl} / \mathrm{m}^{2}$ ) suorakylvetyillä alueilla, kun taas syyskynnetyillä ruuduilla maanpinnalle syksyllä varisseet rikkakasvien siemenet olivat muokkaantuneet syvälle.

Kun rikkakasvit torjuttiin ensimmäisenä kasvukautena (2001) normaalisti kesäkuussa, ei lokakuun lopun havainnossa ollut talvehtimaan jääviä saunakukkia tai muita hankalia rikkakasvilajeja.

Toisena keväänä (2002) kynnössä haudatut peltomataran siemenet oli kynnetty pintaan ja koko kokeen alueella taimettui paljon mataraa $\left(200-550 \mathrm{kpl} / \mathrm{m}^{2}\right)$. Matarat tuhoutuivat herbisidiruiskutuksella, mutta kynnetyillä ruuduilla taimettui käsittelyn jälkeen peippiä

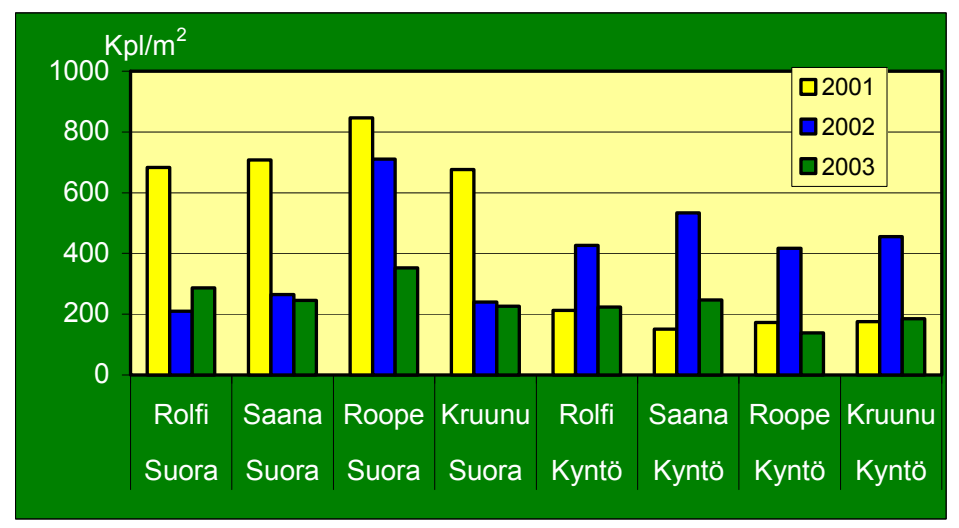

Rikkakasvien taimettuminen eri vuosina Jokioisten suorakylvökokeessa. Havainto keväällä ennen rikkakasvien torjuntaa. Ensimmäisenä vuonna sängelle kylvetyillä ruuduilla taimettui paljon peltomataraa, jonka taimettuminen oli seuraavina vuosina koko koealueella tasaisempaaä. 
Kun maahan varisseita rikkakasvien siemeniä ei syksyllä haudata maan siemenpankkiin on niiden tuhoutuminen maan pinnalla haudattuja siemeniä nopeampaa. Samalla niillä on mahdollisuus itää runsaasti heti keväällä.

Keväällä 2003 rikkakasveja taimettui kynnetyillä ruuduilla keskimäärin $190 \mathrm{kpl} / \mathrm{m}^{2}$ ja suorakylvetyillä $270 \mathrm{kpl} / \mathrm{m}^{2}$, ero on merkitsevästi kynnetyn eduksi $(\mathrm{P}<0,016)$. Skuterud et al. (1996) painottavatkin siemenrikkakasvien tehokkaan torjumisen tarvetta suorakylvettäessä.

Kolmantena keväänä siemenrikkakasvien lajisto on alkanut erota kylvömenetelmien välillä. Suorakylvettäessä linnunkaali ja peltomatara olivat yleisimmät leveälehtiset siemenrikkakasvit. Kynnetyllä alueella on myös peltomataraa on runsaasti, mutta peippiä ja jauhosavikkaa on kynnetyilla ruuduilla muokkaamattomia koejäseniä enemmän. Myös Vanhala ja Pietola (2003) havaitsivat jauhosavikan ja punapeipin viihtyvän paremmin kynnettäessä kuin kevennettyä muokkausta käytettäessä. Swanton et al. (1999) ja Tørresen (1998) taas korostavat jauhosavikan ja kynnön yhteenkuulumista.

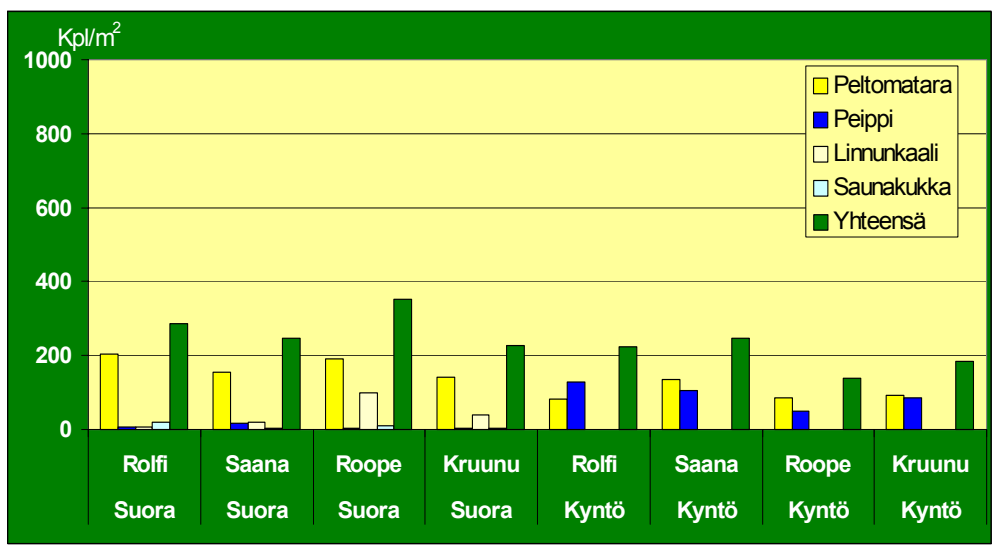

Suorakylvökokeen kolmantena keväänä rikkakasvilajisto erosi kylvömenetelmien välillä. Havainto keväällä ennen rikkakasvien torjuntaa. Suorakylvettäessä linnunkaali ja peltomatara olivat yleisimmät leveälehtiset siemenrikkakasvit, muokattuun maahan kylvettäessä taas peippi ja peltomatara

Kolmen koevuoden aikana ei Jokioisten kokeeseen taimettunut pelto-ohdaketta tai peltovalvattia. Pelto-ohdake tai peltovalvatti eivät erityisesti liity muokkauksiin tai suorakylvöön, etenkin jos kemiallisesta torjunnasta pidetään huolta (Derksen et al. 1993).

Syysmuokkauksesta luovuttaessa lisääntyvät pientareiden ja muokkaamattomien alueiden rikkakasvit. Juolavehnä ei ole lisääntynyt, koska kokeissa ei entuudestaan ollut juolavehnä vaivana eivätkä muokkausvälineet sen juurakoita alueelle kuljettaneet. Muokkausvälineiden juolavehnää levittävään vaikutukseen viittaa myös Cussans (1975).

Sen sijaan timoteimättäitä alkoi kasvaa muokkaamattomilla ruuduilla ja syksyllä 2003 kokeessa kasvoi timotetä ja kylänurmikkaa. Myös aikaisemmissa tutkimuksissa on havaittu, että käytettäessä perusmuokkauksena kyntöä kevyempiä menetelmiä erityisesti heinämäiset rikkakasvit lisääntyvät (Cussans 1975, Tørresen et al. 1999, Gruber et al. 2000, Streit et al. 2000).

\section{Johtopäätökset}

Jokioisilla tehdyssä suorakylvökokeissa on käynyt selville pellon rikkakasvillisuuden tarkkailun tehostamisen tarve suorakylvöön siirryttäessä. Kolmen vuoden jälkeen juurien/juurakon avulla leviävät ja säilyvät juuririkkakasvit eivät ole lisääntyneet. Kevätitoisten rikkakasvien taimettuminen on kolmen vuoden jälkeen lisääntynyt. Maan muokkauksen lopettamien on antanut mahdollisuuden mätästäville siemenlevintäisille heinille, kuten timotei, polvipuntarpää ja kylänurmikka.

\section{Kirjallisuus}

Cussans, G.W. 1975. Weed control in reduced cultivation and direct drilling systems. Outlook on agriculture. Special number 8: 240-242. ISSN: 0030-7270

Derksen, D.A., Lafond, G.P., Thomas, A.G., Loeppky, H.A. \& Swanton, C.J. 1993. Impact of agronomic practices on weed communities: Tillage systems. Weed science 41: 409-417 ISSN 0043-1745 
Gruber, H., Händel, K. \& Broschewitz, B. 2000. Einfluß der Wirtschaftsweise auf die Unkrautflora in Mähdruschfrüchten einer sechsfeldringen Fruchtfolge. Zeitschrift für pflanzenkrankheiten und pflanzenschutz, sonderheft XVII 33-40 ISSN: 0340-8159

Skuterud, R., Semb, K., Saur, J. \& Mygland, S. 1996. Impact of reduced tillage on the weed flora in spring cereals. Norwegian journal of agricultural sciences. 10: 519-532 ISSN: 0801-5341

Streit, B., Stamp, P. \& Richner, W. 2000. Einfluß von unterschiedlicher Bodenarbeitungsintensität auf die Entwicklung von Unkrautpopulationen in Ackerkulturen. Zeitschrift für pflanzenkrankheiten und pflanzenschutz, sonderheft XVII 341-46. ISSN: 0340-8159

Swanton, C., J., Shrestha, A., Roy, R., C., Ball-Coelho, B., R. \& Knezevic, S., Z. 1999: Effect of tillage systems, N, and cover crop on the composition of weed flora. Weed Science 47, No. 4: 454-461. ISSN 0043-1745

Tørresen, K.S. 1998. Emergence and longevity of weed seeds in soil with different tillage treatments. In. (eds.) Champion, G.T, Grundy, A.C., Jones, N.E., Marshall, E.J.P. \& Froud-Williams, R.J. Weed seedbanks: determination, dynamics \& manipulation. Assosiation of applied biologists at St. Catherine's College, England on the 23 and 24 March 1988. Warwick, UK: Assosiation of applied biologists. p. 197-204.

Tørresen, K.S. Skuterud, R., Weiseth, H.J., Tandsæether, H.J. \& Jonsen, S.H. 1999. Plant protection in spring cereal production with reduced tillage. I. Grain yield and weed development. Crop protection 18: 595603.

Vanhala, P. \& Pietola, L. 2003. Effect of conservation tillage and peat application on weed infestation on a clay soil. Agricultural and Food Science in Finland 12:133-145. ISSN 1239-0992 